\title{
TINJAUAN FIQIH MUAMALAH TERHADAP PRAKTEK BISNIS COST PER ACTION (CPA): STUDI KASUS DI WWW.ACCESSTRADE.CO.ID
}

\author{
Firmansyah $^{1}$ dan Muhammad Hafizh ${ }^{2}$
}

1Program Studi Perbankan Syariah, Sekolah Tinggi Ekonomi Islam SEBI, Depok, Jawa Barat. Email: firm134@gmail.com

2Program Studi Perbankan Syariah, Sekolah Tinggi Ekonomi Islam SEBI, Depok, Jawa Barat. Email: hafizhpreneur@gmail.com

\begin{abstract}
ABSTRAK: Tujuan penelitian ini adalah untuk mengetahui akad yang digunakan di dalam sistem CPA antara advertiser, Access Trade, publisher dan untuk mengetahui praktek bisnis yang diterapkan apakah sudah memenuhi prinsip muamalah. Penelitian ini merupakan penelitian deskriptif kualitatif dengan menggunakan metode penelitian lapangan (field research), dan jika mengacu pada pokok permasalahan dan tujuan penelitian, maka penelitian ini termasuk penelitian studi kasus (case study). Sedangkan dalam pengumpulan data menggunakan dokumentasi naskah dan penulis berpartisipasi dalam program CPA ini. Penulis menganalisis data ini dengan menggunakan metode analisis deskriptif yaitu usaha mengumpulkan dan menyusun suatu data, kemudian dilakukan analisis dan interpretasi terhadap data tersebut, dengan kata lain memberikan gambaran yang jelas dan akurat tentang masalah yang diselidiki. Dalam prakteknya sistem CPA ada tiga pihak yang ikut andil, yaitu advertiser, Access Trade, dan publisher. Dalam hubungan hukumnya, terdapat dua hubungan dan masing-masing akad yaitu antara advertiser dengan publisher menggunakan akad ijarah dan publisher dengan Access Trade menggunakan akad ju'alah. Hasilnya adalah pelaksanaan sistem CPA di www.accesstrade.co.id ini tidak menyimpang dari hukum islam.
\end{abstract}

Kata Kunci: Cost Per Action, Advertiser, Access Trade, Publisher dan Jua'alah

\begin{abstract}
The purpose of this study was to determine the contract used in the CPA between the advertiser system, Access Trade, publisher and business practices to determine whether it meets the principles applied muamalah. This research is a qualitative descriptive study using field research, and if it refers to the subject matter and purpose of the study, the study includes a case study. Whereas in the collection of data using the script documentation and writers participating in this CPA program. Authors analyzed these data using descriptive analysis method is an effort to collect and compile the data, then analysis and interpretation of the data, in other words give a clear and accurate picture of the problem investigated. In practice the CPA system, there are three parties took part, namely the advertiser, Access Trade, and publisher. There are two relationships and each contract is between the advertiser and the publisher using Ijarah contract publisher with Access Trade using ju'alah contract. Te result shown tha the implementation of the CPA in www.accesstrade.co.id system does not violate the Islamic law.
\end{abstract}

Keywords: Cost Per Action, Advertiser, Access Trade, publisher and Ju'alah 


\section{PENDAHULUAN}

Transaksi jual beli merupakan kegiatan yang sudah lama di kerjakan orang-orang sejak dahulu. Jual beli di dalam Islam termasuk pada bagian muamalah, hal ini menjadikan setiap kegiatan transaksi jual beli yang dilakukan telah diatur oleh agama dan secara sistematis. Dengan berkembangannya zaman dan teknologi, penggunaan internet di Indonesia dan dunia pada umumnya terus bertambah, bahkan sudah menjadi sebuah gaya hidup bagi sebagian penduduk dunia. Hal ini tentu memberikan dampak pola interaksi jual beli. Perkembangan ini memberikan banyak peluang bagi para pelaku bisnis secara offline untuk terjun dalam bisnis melalui Internet yang biasa disebut Online Shop atau E-commerce.

Perkembangan E-commerce ini semakin memperlebar peluang bagi seseorang untuk memulai bisnisnya sendiri. Salah satu faktor penyebabnya adalah adanya fitur unik dari E-commerce yang dinamakan global reach. Keunikan dari E-commerce ini membuat niche market (ceruk pasar) terlalu kecil untuk digarap menjadi cukup besar (Prasetio, 2012). E-commerce ini di dukung dengan banyaknya pengguna internet, khususnya di Indonesia.

Grafik 1. 1 Jumlah Pengguna Internet di Indonesia

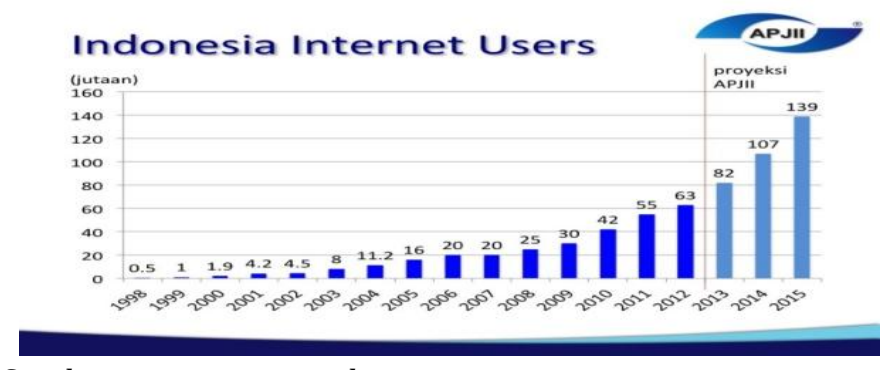

Sumber : www.apjii.or.id

Dari statistik di atas, dapat diambil kesimpulan bahwasanya pengguna internet terus meningkat, dan di proyeksikan akan lebih meningkat lagi menjadi 139 juta pada tahun 2015. Jika calon pembeli datang ke toko sehari 50 orang mungkin sudah biasa, jika yang datang 5.000 orang mungkin ini sudah sangat besar, tetapi bisa di bayangkan jika 6.300 .000 orang (10\% dari 63 juta) yang datang ke toko untuk membeli, begitu besar potensi untuk menjadikan usaha dari offline menjadi online.

Dengan hadirnya internet, barang atau produk-produk dapat dipasarkan secara efisien baik dari sisi waktu maupun tenaga. Cukup memasang iklan di web, masyarakat seluruh dunia dapat melihat barang atau produk yang diinginkan dalam hitungan detik. Seiring dengan terus bertambahnya pengguna layanan internet, semakin murah dan mudah untuk mendapatkan layanan internet, serta di dukung oleh peningkatan produktifitas pengusaha yang menyediakan berbagai produk untuk dipasarkan, usaha jual beli melalui internet ini tentu sangat menjanjikan. Jual beli online terhitung mudah untuk dijalankan, karena tidak memerlukan modal yang besar. Cukup dengan adanya foto produk dan akses internet untuk memasarkannya, usaha ini sudah dapat berjalan. Terbukti dengan banyaknya transaksi yang telah terjadi, khususnya di tempat penyedia E-commerce yang sudah terkenal, seperti kaskus, toko bagus, bhineka, dan lainlain. Berikut data transaksi : 
Tabel 1. 1 Data Transaksi E-commerce Terkenal Indonesia

\begin{tabular}{|c|c|c|}
\hline E-commerce & Daily page view & Nilai transaksi/bulan \\
\hline Kaskus.co.id & 3.282 .582 & Rp.575.000.000.000 \\
\hline Bhineka.com & 284.090 & Rp. 25.000 .000 .000 \\
\hline Tokopedia.com & 212.642 & Rp. 8.000 .000 .000 \\
\hline Zalora.co.id & 116.266 & Rp. 720.000 .000 .000 \\
\hline Tokobagus.com & 800.000 & Rp.1.400.000.000.000 \\
\hline
\end{tabular}

Sumber : Data diolah dari berbagai sumber

Model bisnis di internet yang cukup mudah adalah bisnis melalui program Affiliate marketing dengan perusahaan yang memiliki toko online atau transaksi yang dapat dibayar via online. Afiliasi merupakan salah satu metode penjualan barang atau jasa dengan memanfaatkan bantuan pihak lain. Pada setiap penjualan yang berhasil dilakukan, situs yang memasang link affiliate akan memperoleh komisi. Link tersebut dapat berupa link teks maupun banner iklan. Metode penjualan seperti merupakan metode penjualan yang sangat popular karena sangat mudah untuk dikerjakan. Affiliate marketing sangat cocok untuk pemula yang baru mendalami bisnis online, bahkan banyak para jutawan yang lahir dari bisnis affiliate ini. Banyak kelebihan yang didapatkan pada bisnis affiliate marketing, yaitu tidak ada biaya produksi, biaya awal yang relatif rendah, tidak perlu adanya karyawan, tidak repot mengirim barang karena langsung sistem yang menjalankan, bekerja dari rumah, dapat menjangkau seluruh dunia penjualannya.

Satu cara untuk meningkatkan omset penjualan adalah dengan beriklan di internet, advertiser (pengiklan) dapat mengiklankan produknya di blog atau website yang sudah banyak pengunjung. Acces Trade merupakan penengah yang mempertemukan antara advertiser dan publisher (pemilik blog atau website) dengan menggunakan sistem CPA (cost per action). Advertiser mempercayakan sistem iklan kepada Access Trade, kemudian publisher akan mendapatkan komisi dari Acces Trade jika pengunjung websitenya melakukan action pada link text, banner ads, atau custom link yang ada pada website tersebut. Action tersebut dapat berupa penjualan, download, atau hanya mendaftar.

Menjadi affiliate marketer pada program CPA untuk saat ini banyak digeluti karena dengan prosedur yang mudah dan bebas biaya untuk mendaftarnya, selain itu dapat menghasilkan penghasilan yang luar biasa. Contohnya pada perhitungan ini, jika ada terjadi sehari 20 action dan mendapatkan Rp 3.000 maka sebulan dapat menghasilkan Rp 1.800.000, itu apabila publisher memilih iklan yang per actionnya dengan komisi Rp 3.000, jika publisher memilih iklan yang per actionnya mendapat komisi Rp 200.000 dan sehari terjadi 5 action maka sebulan bisa mendapatkan Rp 30.000.000

Bisnis dengan menggunakan sistem CPA ini masih terdapat kelemahan didalamnya, sebagai contoh untuk bergabung di dalam Access Trade, tanpa negoisasi pemilik situs wajib membuat kesepakatan yang dibuat secara sepihak oleh Access Trade, sehingga akad atau perjanjian sepenuhnya dibuat oleh pihak Access Trade dan orang yang akan bekerjasama atau bergabung di dalam program CPA Access Trade harus menyepakati peraturan yang dibuat oleh Access Trade. Selain itu Access Trade berhak 
memberikan banned atau mengeluarkan publisher jika terjadi kecurangan dengan melanggar TOS yang telah dibuat oleh Access Trade.

Untuk mendapatkan komisi, publisher harus mencapai minimal pay out atau target yang harus dipenuhi agar komisi bisa cair walaupun publisher telah bekerja untuk promosi selama satu bulan bahkan sampai setahun dan tidak mencapai minimal pay out maka publisher tidak akan dibayar oleh Access Trade. Selain itu pihak advertiser sebagai pengiklan tidak berhubungan langsung kepada publisher yang sejatinya membayar setiap action mereka.

Seiring dengan perkembangan teknologi, konsep bisnis mengalami perubahan cara, yakni sebuah bisnis (khususnya CPA) tidak lagi dilakukan dalam mempertemukan para pihak (Access Trade, publisher, advertiser) dan barang dalam satu majelis, tetapi cukup dengan teknologi internet sebagai media komunikasi bagi mereka. Hal ini tentunya akan berpengaruh terhadap sah atau tidaknya akad bisnis melalui internet.

Dalam sebuah sistem (khususnya CPA) tidak menutup kemungkinan adanya celah untuk melakukan tindakan kecurangan, misalnya advertiser yang tidak melaporkan secara lengkap kepada pihak Access Trade dan publisher data konversi yang telah dihasilkannya atau pihak publisher yang dapat memanipulasi setiap action yang dihasilkannya dengan data yang tidak benar/valid. Bisnis periklanan dengan sistem CPA merupakan salah satu transaksi bisnis dengan menggunakan media internet, meskipun demikian bisnis ini tetap menggunakan akad. Oleh karena itu penulis tertarik untuk meneliti dan membahas kerjasama dalam sistem yang Acces Trade tetapkan kepada publisher dan advertiser berdasarkan tinjauan fikih muamalah.

Berdasarkan uraian di atas, penulis tertarik untuk menelaah Tinjauan Fikih Muamalah Terhadap Praktek Bisnis Cost Per Action (CPA) Antara Advertiser, CPA Network, dan Publisher dalam hal ini focus kajiannya adalah accestrade.com.

\section{TELAAH PUSTAKA}

\section{Pengertian Cost per Action (CPA)}

Cost per Action (CPA) adalah sistem yang mana penerbit akan mendapatkan pembayaran untuk setiap action yang terjadi, action itu dapat berupa penjualan, pendaftaran online, download, dan lainnya (Helft. 2007). Intinya Cost per Action (CPA) adalah program dimana publisher akan mendapatkan komisi jika terjadi action pada setiap link affiliate yang telah dimiliki masing-masing publisher Access Trade. Dalam program CPA, terdapat 3 pihak yang ambil andil dalam berjalannya program ini, yaitu Access Trade, publisher, dan advertiser :

a. Access Trade: Yaitu pihak yang menyediakan sebuah sistem periklanan modern di internet, yang menawarkan sistem Cost per Action (CPA).

b. Publisher: Yaitu pemilik dari media yang memberikan informasi kepada pembaca di internet. Contoh publisher antara lain adalah news portal, media komunitas, ataupun sebuah blog.

c. Advertiser: Yaitu pihak yang ingin web/ produknya dipromosikan oleh para Publisher di Access Trade.

\section{Kelebihan Cost per Action Dari Sistem Lainnya}

Selain sistem Cost per Action, sebelumnya ada dua sistem periklanan yang sangat terkenal di kalangan advertiser, yaitu cost per impresion (CPM) dan cost per click (CPC). 
Dalam model CPM, pengiklan membayar setiap tayangan iklan mereka (Nazerzadeh, et.al, 2008). Sistem CPM umumnya digunakan oleh media seperti majalah, televisi, atau iklan banner dan sistem iklan ini lebih cocok untuk meningkatkan brand awareness (memperkenalkan merk). Dengan terus pesatnya perkembangan pengguna internet, semakin kesini model iklan dengan sistem cost per click mengalami kemajuan, di mana pengiklan hanya membayar jika pengguna mengklik iklan mereka (Nazerzadeh, et.al, 2008). Bahkan model sistem CPC diadopsi langsung oleh mesin pencari terkenal dunia, seperti Google dan Yahoo untuk penempatan iklan di hasil pencarian mereka.

Dalam skema sistem CPA ada beberapa keuntungan yang lebih unggul daripada sistem periklanan lainnnya, berikut beberapa keuntungan dari sistem Cost per Action (Mahdian dan Tomak, 2007) :

1. Salah satu kelemahan dari sistem CPC adalah rentan dengan penipuan klik dari publisher atau pihak lain yang memang tidak berniat untuk mengklik iklan tersebut. Tantangan terbesar inilah yang menjadi ancaman serius bagi industri pengiklan online.

2. Untuk tingkat konversi, model iklan CPA lebih meyakinkan daripada lainnya.

3. Di dalam sistem CPM atau CPC, penghitungan jumlah tayangan atau klik harus mempercayai penerbit dan ini dapat merugikan advertiser jika terjadi tayangan atau klik melalui bot atau robot.

\section{Tantangan Sistem Cost per Action}

Masalah utama dalam sistem ini adalah asumsi dari publisher bahwa advertiser akan suka rela memberikan data setiap action yang didapat melalui link affiliatenya, tetapi pada kenyataannya tidak demikian, jikalau memberi pun ada beberapa indikasi kecurangan di dalam pelaporan setiap action yang didapatkan (Mahdian dan Tomak, 2007) :

1. Jika terjadi action, maka disini pihak advertiser bisa melakukan kecurangan dalam pelaporan setiap actionnya. Misalnya jika terjadi action yang dilakukan oleh seorang publisher, maka yang hanya diterima publisher tidak semuanya, tetapi sebagian saja.

2. Karena rumit dan mahal dalam alat pengumpulan data masing-masing action yang berupa penjualan, pengisian data, ataupun download, pihak advertiser tidak memilikinya. Ada beberapa para pengiklan tidak memiliki/menggunakan alat mempermudah pelacakan setiap action yang terjadi dan ini membuat publisher tidak bisa melakukan memfollow up.

3. Sebagian besar advertiser memberlakukan sebuah data konversi mereka begitu sangat berharga, sehingga sangat memperhitungkan ketika memberikan semua datanya (walaupun terhadap publisher), karena jika pesaing mengetahui akan sangat mudah ditiru bagaimana melakukan konversi yang tinggi.

\section{Prinsip-Prinsip Muamalah}

Muamalat merupakan pergaulan hidup tempat setiap orang melakukan perbuatan dalam hubungannya dengan orang-lain. Muamalat mempunyai beberapa prinsip yang harus dipahami oleh setiap umat muslim, agar dalam melakukan berbagai akad dengan orang lain tidak menyimpang dari ajaran Islam. Salah satu diantara beberapa prinsip muamalah adalah Pada dasarnya segala bentuk muamalat adalah mubah,kecuali yang 
ditentukan lain oleh Alquran dan sunah Rasul. Pada prinsip pertama ini mengandung arti bahwa hukum Islam memberi kesempatan luas perkembangan bentuk dan macam muamalat baru sesuai dengan perkembangan kebutuhan hidup masyarakat. Semakin maju perkembangan zaman, maka bukan tidak mungkin kedepan akan bermunculan berbagai macam konsep bermuamalat. Islam sangat mendukung dengan kemajuan zaman serta perkembangan teknologi, namun perkembangan teknologi itu tetap harus didukung dengan landasan keimanan serta prinsip-prinsip muamalat agar dapat berjalan dengan selaras. (Basyir, 2000).

\section{A. Ijarah}

Al Ijarah berasal dari kata Al Ajru yang berarti Al Iwadhu (ganti). Dari sebab itu Ats Tsawab (pahala) dinamai Ajru (upah) (Sabiq, 1987). Secara etimologi ijarah berasal dari ajara yajuru yang berarti upah yang kamu berikan dalam suatu pekerjaan (Abdullah, et.al, 2009). Menurut pengertian syara', Al Ijarah ialah sesuatu jenis akad untuk mengambil manfaat dengan jalan penggantian (Sabiq 13, 1987). Adapun ijarah secara terminologi adalah transaksi atas suatu manfaat yang mubah yang berupa barang tertentu atau yang dijelaskan sifatnya dalam tanggungan dalam waktu tertentu, atau transaksi atas suatu pekerjaan yang diketahui dengan upah yang diketahui pula.

Adapun definisi ijarah yang disampaikan oleh kalangan fuqaha antara lain sebagai berikut (Mas'adi, 2002) : menurut fuqaha Hanafiyah, ijarah adalah akad atau transaksi terhadap manfaat dengan imbalan. Menurut Fuqaha Syafi"iyah, ijarah adalah transaksi terhadap manfaat yang dikehendaki secara jelas harta yang bersifat mubah dan dapat dipertukarkan denngan imbalan tertentu. Munurut Fuqaha Malikiyah dan Hanabilah, ijarah adalah pemilikan manfaat suatu harta benda yang bersifat mubah selama periode waktu tertentu dengan suatu imbalan.

Manakala akad sewa menyewa telah berlangsung, penyewa sudah berhak mengambil manfaat. Dan orang yang menyewakan berhak pula mengambil upah, karena akad ini adalah mu'awadhah (penggantian) (Sabiq 13, 1987).

\section{Rukun dan Syarat Ijarah}

Rukun ijarah ada empat beserta syarat yang harus dipenuhi untuk keabsahan rukun tersebut, yaitu dua belah pihak yang melakukan akad, shighah ijarah, imbalan (ujrah), dan hak pakai (manfaat). Sedangkan mengenai syaratnya sebagai berikut:

\section{a). Dua belah pihak yang melakukan akad}

Pihak pertama disebut orang yang menyewakan (mu'ajir) dan pihak kedua disebut (musta'jir). Keduanya harus memenuhi persyaratan yang berlaku bagi penjual dan pembeli. Diantaranya mereka harus cakap, artinya masing-masing pihak sudah baligh dan mampu menata agama dan mengelola kekayaan dengan baik. Dengan demikian ijarah yang dilakukan oleh anak-anak meskipun dia telah memiliki pengetahuan tentang itu, orang gila, dan orang yang dicekal untuk membelanjakan hartanya bodoh, meskipun akad tersebut mendatangkan keuntungan, hukumnya tidak sah.

Persyaratan berikutnya adalah mu'jir mampu menyerahkan manfaat barang. Karena itu, tidak sah hukumnya menyewa barang ghashaban kepada orang yang tidak mampu mengambil alih barang tersebut setelah kesepakatan akad. Begitu pula, tidak sah menyewakan tanah gersang untuk bercocok tanam, yaitu tanah yang tidak bisa menyerap air, baik air hujan musiman atau lelehan air salju dari atas bukit. Hukum 
barang yang tidak boleh disewakan karena larangan syar'i sama dengan larangan yng bersifat kongkret, seperti yang telah disebutkan sebelumnya (Zuhaili, 2010)

\section{c). Imbalan (Ujroh)}

Dalam hal sewa-menyewa barang yang berwujud (ijarah ain), disyaratkan upah harus diketahui jenis, kadar, dan sifatnya, layaknya harga dalam akad jual-beli. Karena ijarah merupakan akad yang berorientasi keuntungan, yaitu tidak sah tanpa menyebutkan nilai kompensasi layaknya jual-beli. Oleh karena itu, para ulama sepakat menyatakan bahwa khamr dan babi tidak boleh menjadi upah dalam akad ijarah, karena kedua benda itu tidak bernilai harta dalam islam (Nasrun, 2007).

Adapun imbalan tersebut berupa barang yang berwujud, musta'jir cukup dengan melihatnya, meskipun itu diperuntukan untuk kompensasi manfaat tertentu atau dalam bentuk tanggungan, sementara itu menyewa manfaat suatu barang dengan imbalan manfaat sejenis atau berbeda hukumnya boleh, sebab manfaat dalam akad ijarah statusnya sama dengan barang. Dan barang boleh diperjual-belikan dengan barang sejenis, sama dengan manfaat.

Uang sewa menjadi hak milik mu'jir yang dilindungi hukum dan sepanjang waktu, begitu akad ijarah disepakati. Artinya ketika masa persewaan sudah habis, kompensasi tersebut tetap menjadi haknya. Jadi kepemilikan mu'jir atas uang tersebut sebagai hasil penyewaan barang telah berkekuatan hukum (Nasrun, 2007).

\section{d). Hak Pakai (manfaat)}

Manfaat barang yang di sewakan, seperti rumah misalnya, harus memenuhi beberapa syarat, baik sewa-menyewa itu secara langsung maupun dalam tanggungan, beberapa syarat tersebut sebagai berikut:

1. Manfaat barang memiliki nilai ekonomis yang layak mendapatkan imbalan sebagai kompensasi penyewaan. Misalnya seperti mengontrakan rumah sebagai tempat tinggal.

2. Manfaat barang yang disewakan tersebut mubah menurut syara, jadi tidak sah menyewakan manfaat yang dilarang oleh agama, seperti menyewakan jasa penari yang diharamkan, menyewakan kedai untuk pesta minuman minuman keras dan narkoba atau sejenisnya, atau mengangkut minuman bukan untuk di musnahkan (Nasrun, 2007).

3. Objek ijarah dapat diserah terimakan dan dimanfaatkan secara langsung dan tidak ada cacat yang menghalangi fungsinya. Tidak dibenarkan transaksi ijarah atas harta benda yang masih dalam penguasaan pihak ke tiga (Mas'adi, 2002).

4. Manfaat diketahui oleh kedua belah pihak yang mengadakan akad, meskipun sekilas. Masing-masing pihak mengetahui manfaat barang yang disewakan dari sisi fisik, sifat, dan kadarnya. Karena itu, menyewakan salah satu dari rumah, dua kedai, atau dua macam barang, hukumnya tidak sah, begitu pula menyewakan barang yang tidak terlihat dan menyewakan tanpa batas waktu, kecuali masuk toilet umum, hukumnya boleh mennurut ijma' ulama.

5. Pemanfaatan barang sewaan dibatasi dengan jangka waktu tertentu, akad ijarah menggunakan jangka waktu yang tidak jelas hukumnya tidak sah. Misalnya mu'jir berkata, "tempatilah rumah ini selama kamu suka", "tanamilah tanah ini" atau "dirikanlah bangunan diatasnya" sebab, ketidaksahan memicu perselisihan. 
6. Mustajir belum mengambil manfaat barang tersebut.

7. Objek ijarah adalah manfaat barang itu sendiri (Zuhaili, 2010).

Ketujuh persyaratan diatas haruslah dipenuhi dalam setiap ijarah yang mentransaksikan manfaat harta benda. Adapun ijarah yang mentransaksikan suatu pekerjaan atas seorang pekerja atau buruh memenuhi beberapa persyaratan sebagai berikut ini (Mas'adi, 2002) :

Pertama, perbuatan tersebut harus jelas batas waktu pekerjaan, misalnya bekerja menjaga rumah satu malam, atau satu bulan. Dan harus jelas jenis pekerjaannya, misalnya pekerjaan menjahit baju, memasak, mencuci dan lain sebagainya. Dalam hal yang disebutkan terakhi ini tidak disyaratkan adanya batas waktu pengerjaannya. Oleh karena itu, dalam hal ijarah pekerjaan, diperlukan adanya job description (uraian pekerjaan). Kedua, pekerjaan yang menjadi objek ijarah tidak berupa pekerjaan yang telah menjadi kewajiban pihak mustajir (pekerja) sebelum terjadi akad ijarah, seperti kewajiban membayar hutang, mengembalikan pinjaman, menyusui anak dan lain sebagainya. Demikian pula tidak sah mengupah perbuatan ibadah seperti shalat, puasa dan lain-lain. Sehubungan dengan prinsip ini terdapat perbedaan pendapat mengenai ijarah terhadap pekerjaan seorang muadzin (juru adzan) imam, dan pengajar ala qur'an, memandikan jenazah. Menurut fuqaha Hanafiyah dan Hanabilah tidak sah. Alasan mereka perbuatan tersebut tergolong pendekatan diri (taqarrub) kepada Allah SWT.

\section{B. Ju'alah}

Akad Ju'alah identik dengan sayembara, yakni menawarkan sebuah pekerjaan yang belum pasti dapat diselesaikan. Jika seseorang mampu menyelesaikan, maka ia berhak mendapatkan upah atau hadiah. Secara harfiah, Ju'alah bermakna sesuatu yang dibebankan kepada orang lain untuk dikerjakan, atau perintah yang dimandatkan kepada seseorang untuk dijalankan. Menurut ahli hukum, Ju'alah diartikan dengan hadiah yang dijanjikan ketika seseorang berhasil melakukan sebuah pekerjaan. Sayyid Sabiq dalam fikih Sunnah menjelaskan : Ju'alah adalah jenis akad atas manfaat sesuatu yang diduga kuat akan diperolehnya (Sabiq, 1988).

Secara istilah, menurut madzhab malikiyyah, Ju'alah adalah akad sewa (ijarah) atas sesuatu manfaat yang belum diketahui keberhasilannya (terhadap probabilitas atas keberhasilan atau kegagalan dalam menjalankan suatu pekerjaan). Seperti halnya ucapan seseorang, barang siapa mampu menggali sumur ini hingga mengalir airnya, maka ia berhak mendapatkan hadiah yang saya janjikan (Djuwaini, 2008).

Madzhab Maliki mendefinisikan Ju'alah: "Suatu upah yang dijanjikan sebagai imbalan atas suatu jasa yang belum pasti dapat dilaksanakan oleh seseorang". Madzhab Syafi'i mendefinisikannya: "Seseorang yang menjanjikan suatu upah kepada orang yang mampu memberikan jasa tertentu kepadanya". Definisi pertama (madzhab Maliki) menekankan segi ketidakpastian berhasilnya perbuatan yang diharapkan. Sedangkan definisi kedua (madzhab Syafi'i) menekankan segi ketidakpastian orang yang melaksanakan pekerjaan yang diharapkan.

Seperti halnya lomba lari maraton, barang siapa yang mampu lebih awal mencapai garis finish, maka ia berhak mendapatkan hadiah. Begitu juga dengan Formula 1, Grand Prix atau yang sejenisnya. Seperti halnya seorang dokter yang mampu menyembuhkan suatu penyakit, atau seorang ulama yang bisa membuat seseorang hafal al-Qur'an. Ulama 
fikih klasik mencontohkan dengan, barang siapa yang bisa menemukan kuda tunggangan atau budaknya yang hilang maka ia berhak mendapatkan hadiah.

Secara logika Ju'alah dapat dibenarkan, karena merupakan salah satu cara untuk memenuhi keperluan manusia, sebagaimana halnya dengan ijarah dan mudharabah (perjanjian kerjasama dagang). Namun, ada beberapa ulama yang melarang akad Ju'alah seperti hanafiyah, madzhab Hanafi tidak membenarkan Ju'alah. Karena dalam Ju'alah terdapat unsur garar, perbuatan yang mengandung garar itu merugikan salah satu pihak dan dilarang dalam Islam (Zuhaili, juz 5, hlm. 512). Madzhab Maliki, Syafi'i dan Hambali memandang, bahwa Ju'alah adalah perbuatan hukum yang bersifat suka rela. Dengan demikian, pihak pertama yang menjanjikan upah atau hadiah, dan pihak kedua yang melaksanakan pekerjaan dapat melakukan pembatalan.

\section{Syarat Akad Ju'alah}

Secara esensial pada Ju'alah disyaratkan supaya nyata (jelas), maka syarat-syarat jelasnya Ju'alah adalah sebagai berikut :

1). Kalimat atau lafadz yang menunjukkan izin pekerjaan, yang merupakan syarat atau tuntunan dengan takaran tertentu (Asy Syarbini, 1997). Bila seseorang mengerjakan perbuatan, tetapi tanpa seizin orang yang menyuruh (yang punya barang), maka baginya tidak ada (tidak memperoleh) suatu apapun, jika barang itu ditemukannya. Madzhab Maliki, Syafi'i dan Hambali berpendapat, bahwa agar perbuatan hukum yang dilakukan dalam bentuk Ju'alah itu dipandang sah, maka harus ada ucapan (sigah) dari pihak yang menjanjikan upah atau hadiah, yang isinya mengandung izin bagi orang lain untuk melaksanakan perbuatan yang diharapkan dan jumlah upah yang jelas tidak seperti iklan dalam surat kabar yang bisaanya tidak menyebutkan imbalan secara pasti. Ucapan tidak mesti keluar dari orang yang memerlukan jasa itu, tetapi boleh juga dari orang lain seperti wakilnya, anaknya atau bahkan orang lain yang bersedia memberikan hadiah atau upah. Kemudian Ju'alah dipandang sah, walaupun hanya ucapan Ijab saja yang ada, tanpa ada ucapan Qabul (cukup sepihak).

2). Keadaan Ju'alah (upah yang akan diberikan) hendaknya ditentukan, uang atau barang, sebelum seseorang mengerjakan pekerjaan itu (Suhendi, 2005).

Dan berikut beberapa ulama' memberikan beberapa syarat terkait dengan keabsahan akad Ju'alah, yaitu sebagai berikut (Djuwaini, hlm. 169) :

1). Orang yang terlibat dalam akad Ju'alah harus memiliki ahliyyah. Ja'il (pemilik sayembara) haruslah orang yang memiliki kemutlakan dalam transaksi (baligh, berakal dan rasyid), tidak boleh dilakukan oleh anak kecil, orang gila atau safih. Untuk amil (pelaku) haruslah orang yang memiliki kompetensi dalam menjalankan pekerjaan, sehingga ada manfaat yang bisa dihasilkan.

2). Hadiah, upah yang diperjanjikan harus disebutkan secara jelas jumlahnya. Jika upahnya tidak jelas, maka akad Ju'alah batal adanya. Karena ketidak jelasan kompensasi.

3). Manfaat yang akan dikerjakan pelaku (amil) haruslah jelas dan diperbolehkan secara syar'i. tidak diperbolehkan menyewa tenaga paranormal untuk mengeluarkan jin, praktek sihir, atau perkara haram lainnya. Kaidahnya adalah, setiap aset yang boleh dijadikan sebagai objek transaksi dalam akad ijarah, maka dibolehkan juga penggunaannya dalam akad Ju'alah, vice versa. Namun demikian, akad ijarah lebih 
umum dan kompleks daripada akad Ju'alah. Madzhab Syafi'iyah menambahkan, setiap pekerjaan (manfaat) yang dilakukan haruslah mengandung beban (usaha), karena tidak ada kompensasi tanpa adanya usaha (risk versus return).

4). Madzhab Malikiyah menambahkan satu syarat, akad Ju'alah tidak boleh dibatasi dengan jangka waktu. Namun ulama lain memperbolehkan perkiraan jangka waktu dengan pekerjaan yang ada.

5). Malikiyyah mensyaratkan, jenis pekerjaan Ju'alah haruslah spesifik, walaupun terbilang.

\section{METODE PENELITIAN}

\section{Jenis Penelitian}

Jenis penelitian yang digunakan dalam penelitian ini adalah deskriptif kualitatif. Penelitian kualitatif adalah penelitian yang dilakukan untuk mengetahui nilai variabel mandiri, baik satu variabel atau lebih (independen) tanpa membuat perbandingan, atau menghubungkan dengan variabel yang lain (Sugiyono, 2003). Dalam penelitian ini penulis ingin menggambarkan sebagai kegiatan yang mengumpulkan, menyusun, dan mendeskripsikan berbagai dokumen, data, dan informasi yang aktual yang bertujuan untuk menjelaskan permasalahan mengenai tinjauan fikih muamalah terhadap akad kerjasama advertiser, publisher dan Access Trade sampai menemukan jawaban yang diharapkan.

\section{Sumber Data}

Data primer adalah data yang langsung diperoleh dari lapangan melalui percobaan, survei dan observasi, dalam arti data yang diperoleh langsung dari sumber asli tidak melalui media perantara (Lungan, 2006). Pada penelitian ini penulis tidak menggunakan data primer. Data sekunder adalah data yang tidak langsung memberikan data kepada peneliti, misalnya peneliti harus melalui orang lain atau mencari melalui dokumen. Data ini diperoleh dengan menggunakan studi literatur yang dilakukan terhadap banyak buku (Sugiyono, 2003). Pada penelitian ini, bahan yang digunakan untuk data sekunder adalah kitab klasik maupun kontemporer, jurnal, website resmi AccessTrade.com, makalah yang berkaitan dan relevan dengan permasalahan yang akan dikaji.

\section{Teknik Analisis Data}

Analisis data adalah proses mengorganisasikan dan mengurutkan data ke dalam pola, kategori dan satuan uraian dasar sehingga dapat ditemukan tema dan dapat disarankan oleh data (Moleong, 2004). Teknik analisis data yang digunakan pada penelitian ini adalah dengan metode analisis deskriptif yaitu usaha mengumpulkan dan menyusun suatu data, kemudian dilakukan analisis dan interpretasi terhadap data tersebut (Surakhmad, 1990). Dengan kata lain memberikan gambaran yang jelas dan akurat tentang masalah yang diselidiki..

\section{HASIL DAN ANALISIS}

\section{Mekanisme Yang Diterapkan Situs www.AccessTrade.com}

Untuk mendapatkan upah atau komisi dari situs www.AccessTrade.com, calon member atau anggota harus terlebih dahulu memenuhi beberapa prosedur yang ditetapkan langsung oleh pihak www.AccessTrade.com, selengkapnya akan dibahas bagaimana cara mendaftar menjadi publisher sampai ke pencairan komisi atau payout.

\section{a) Cara Mendaftar Menjadi Publisher www.AccessTrade.com}


Ada beberapa langkah step by step yang akan di jelaskan disini melalui gambar agar lebih jelas.

1. Mengakses www.AccessTrade.com : Disini calon member banyak disediakan pilihan tab menu, untuk mendaftar menjadi publisher, maka tahap selanjutnya adalah memilih tab tombol daftar.

2. Klik Pilihan Daftar: Langkah ke dua ini cukup mudah yaitu dengan melanjutkan dengan mengklik tombol daftar (call to action) di Halaman Depan Situs www.AccessTrade.co.id.

3. Ada dua opsi pilihan antara perorangan atau perusahaan, karena disini penulis lebih membahas lebih ke individu, maka dengan memilih opsi perorangan sudah dapat mendaftar menjadi publisher.

4. Langkah selanjutnya adalah diberikan option form yang harus di isi dengan kolom alamat email, alamat blog atau website, kata sandi, dan konfirmasi kata sandi. Isi semua form tersebut kemudian klik daftar dan yang paling penting adalah segera cek email yang didaftarkan untuk konfirmasi link yang diberikan.

5. Setelah melakukan langkah-langkah diatas, publisher sudah dapat login ke member area untuk mengisi biodata secara lengkap serta penjelasan web atau blog yang telah publisher daftarkan, lalu tahap berikutnya memilih iklan yang publisher inginkan.

\section{Cara Mengambil Link Affiliate di Acces Trade Untuk Promosi}

Setelah melakukan tahap pendaftaran sebagai publisher Acces Trade, langkah selanjutnya adalah mengambil link affiliate untuk dipromosikan. Fungsi dari link affiliate ini adalah yang mendaftar sebagai publisher pada sebuah perusahaan CPA tentulah banyak, oleh karena itu para publisher memiliki link affiliate mereka masing-masing, jika terjadi action melalui link affiliate yang mereka miliki masing-masing maka akan mendapatkan komisi.

Berikut beberapa menu yang terdapat pada member area Access Trade dan cara mengambil link affiliate untuk dipasarkan.

1. Login ke Member Area Acces Trade: Pertama adalah login terlebih dahulu untuk masuk ke member area dengan mengklik tab publisher masuk, kemudian akan muncul opt in form email dan password, Form email tersebut di isi dengan email publisher yang sama saat mendaftar Access Trade, begitu juga passwordnya. Setelah mengisi email dan password (kata sandi), klik masuk dan publisher sudah berhasil ke member area.

2. Menu-Menu yang Terdapat Pada Member Area: Tahap ke dua setelah masuk ke member area, di side bar sebelah kiri telah disediakan beberapa menu yang dapat di edit oleh publisher, yaitu berupa manage profile, campaign, report, F.A.Q, dan tutorial.

a. Manage Profil: Menu ini memungkinkan publisher untuk mengedit info profil diri, akun, website, dan akun bank. Dan yang terakhir adalah bagian info website, publisher disini wajib mengisi dari mulai judul website, url, dan kategori website tersebut berada di niche apa. Bisa juga menambahkan website untuk meningkatkan penghasilan dari program $C P A$ ini.

b. Campaign: Pada menu campaign ini adalah bagaimana caranya mengambil link affiliate yang disediakan oleh Access Trade untuk di promosikan. Setelah masuk pada menu campaign, akan ada pilihan seperti gambar dibawah ini: 


\section{Gambar 4. 1 Menu Campaign}

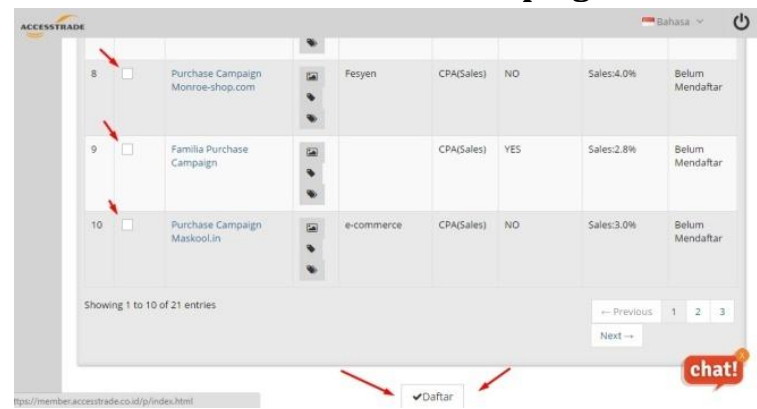

Sumber : www.AccessTrade.co.id

Berikut penampakan beberapa iklan, publisher disarankan memilih iklan sesuai niche web atau blog mereka agar konversinya lebih besar. Untuk memilih iklan apa yang ingin dipasarakan, centang terlebih dahulu seperti gambar diatas kemudian setelah memilih jenis iklan klik DAFTAR di bagian bawah.

Selanjutnya adalah menunggu sampai permohonan publisher disetujui, biasanya sehari setelah daftar langsung dihubungi bahwa publisher diterima untuk memasarkan iklan yang dipasarkannya.

Jika telah diterima campaign yang ingin di promosikan, langkah selanjutnya adalah mengambil link affiliate. Pada menu campaign ada keterangan status terdaftar. Lalu pilih tipe iklan yang publisher inginkan berupa banner, iklan text, atau custom (sesuai kebutuhan), baik itu cara memasarkannya dengan memasang banner di widget blog atau membuat artikel review dari campaign yang dipromosikannya.

\section{Gambar 4. 2 Campaign yang Sudah di Approve}

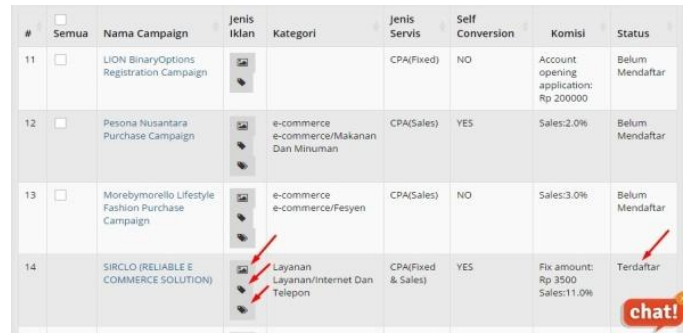

Sumber : www.AccessTrade.co.id

Tahap terkahir, klik tipe iklan yang publisher inginkan. Sebagai contoh dengan mengambil tipe iklan banner, lalu klik tulisan "klik kode" yang bannernya sesuai kebutuhan ingin diletakan dibagian header, footer, ataupun sidebar dan akan muncul kode link affiliasi yang siap publisher pasarkan dan letakkan di website.

Sampai pada tahap ini publisher sudah bisa mendapatkan komisi, dengan syarat komisi yang didapat sudah mencapai minimal payout, yaitu Rp 500.000,--

c. Report: Menu report adalah sebagai tool split test untuk publisher melihat kinerjanya apakah layak diteruskan atau tidak. Menu report ini terbagi menjadi dua, yaitu report laporan harian dan bulanan, seperti gambar dibawah ini: 


\section{Gambar 4. 3 Laporan Harian dan bulanan}
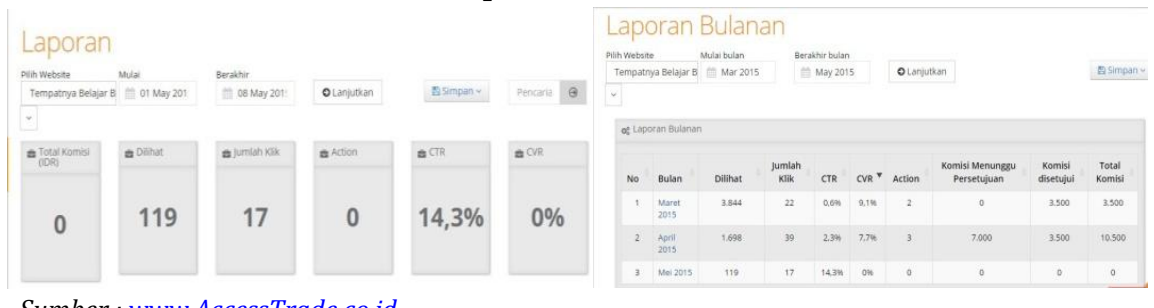

Sumber : $\underline{w w w . A c c e s s T r a d e . c o . i d}$

Pada gambar diatas terlihat jelas bagaimana statistik campaign yang publisher promosikan. Mulai dari berapa orang yang melihat iklan campaign, CTR, action yang terjadi, hingga total komisi.

d. F.A.Q (Frequently Asked Questions): Pada menu F.A.Q ini adalah sebuah daftar pertanyaan dan jawaban yang biasa ditanyakan kepada pihak Access Trade. Pertanyaan-pertanyaan yang terdapat pada F.A.Q Access Trade sebenarnya sudah cukup jelas untuk para membernya, mulai dari apa itu CPA, publisher, Advertiser, kapan bisa menerima komisi, dan lain sebagainya.

e. Tutorial: Pada menu tutorial hanya video singkat dengan durasi 1 menit 40 detik yang menjelaskan bagaimana cara menggunakan dashboard pada Access Trade.

\section{Peran dan Hubungan Antara Publisher, Access Trade, Advertiser}

\section{Publisher}

Publisher adalah pihak yang memasarkan atau pemilik website. Untuk mendapatkan komisi dari Access Trade, publisher berlomba-lomba dalam mendatangkan pengunjung dengan menggunakan strategi SEO (search engine optimization), facebook ads, twitter, ataupun email marketing agar para pengunjung websitenya melakukan action disetiap banner atau artikel review yang dibuat oleh publisher. Dilain sisi publisher memang harus dituntut untuk memiliki skill yang lebih, dalam internet marketing yang harus dikuasainya.

\section{Access Trade}

Access Trade merupakan penyedia layanan sistem CPA (Cost per action), telah diketahui sebelumnya bahwa CPA itu adalah sistem yang mana publisher atau pemilik website akan mendapatkan pembayaran untuk setiap action yang terjadi, action itu dapat berupa penjualan, pendaftaran online, download, dan lainnya sesuai yang ditetapkan oleh Advertiser. Sistem yang telah diterapkan oleh Access Trade merupakan bentuk dari inovasi sebuah marketing online canggih, dengan sistem yang merekam track record setiap action dan hanya sebatas pengunjung yang melihat, dapat diketahui dari sistem yang sudah disediakan Access Trade, jadi publisher tidak dapat berlaku curang ketika mempromosikan program yang hanya membutuhkan data prospek, dengan mengakali mengisi form data melalui data yang tidak valid.

Pada hakikatnya Access Trade menghubungkan antara Advertiser dan publisher, tetapi karena Advertiser telah menyerahkan semua sistem kepada Access Trade dari mulai cara pendaftaran sampai menerima komisi, maka Advertiser sama sekali tidak berhubungan dengan publisher. 


\section{Advertiser}

Pihak selanjutnya adalah Advertiser, yaitu pengiklan yang ingin mengembangkan produk atau jasanya agar semakin dikenal oleh banyak orang. Hubungan antara Access Trade, Advertiser, dan publisher terangkum dalam gambar skema di bawah ini :

Gambar 4. 4 Hubungan Antara Access Trade, Advertiser, dan Publisher

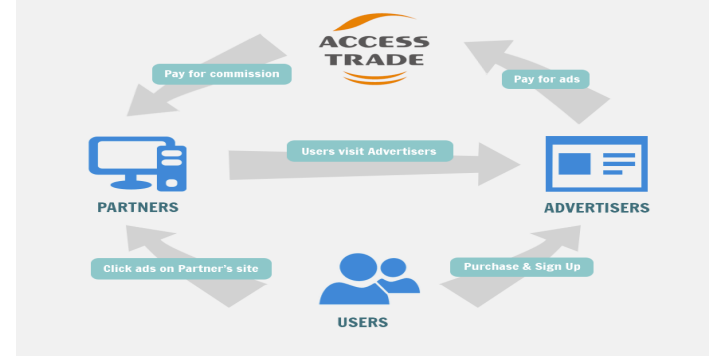

Sumber : www.interspace.co.id

\section{Tinjauan Fikih Muamalah Terhadap Praktek Bisnis CPA Antara Advertiser, Access Trade, dan Publisher}

Cost per action (CPA) adalah program dimana publisher akan mendapatkan komisi jika terjadi action pada setiap link affiliate yang telah dimiliki masing-masing publisher Access Trade. Dalam program CPA, terdapat 3 pihak yang ambil andil dalam berjalannya program ini, yaitu : Access Trade, Publisher dan Advertiser.

Tinjauan fikih muamalah ini akan dilihat dari hubungan hukum antara pihak yang terkait (Access Trade, advertiser, dan publisher) dengan meninjau akad yang digunakan. Jika dilihat dari segi akadnya, menurut penulis ada 2 akad yang digunakan untuk para pihak yang berhubungan pada sistem CPA ini. Pertama akad antara pihak Advertiser kepada Access Trade dan kedua adalah akad antara pihak Access Trade kepada pihak publisher. Untuk akad antara Advertiser dan Access Trade adalah menggunakan akad ijarah, sedangkan antara pihak Access Trade dengan publisher menggunakan akad jua'lah.

\section{Hubungan Hukum Terhadap Sistem CPA Antara Advertiser Kepada Access Trade}

Untuk menaikkan sebuah omset, salah satu faktor yang harus ditingkatkan adalah promosi. Dari sekian banyak strategi promosi, sistem promosi CPA merupakan yang terbaik dalam meningkatkan konversi penjualan. Access Trade adalah penyedia sistem Cost per action tersebut, dengan sistem yang telah terbukti keampuhannya ini, banyak para pemilik bisnis mempromosikan produknya ke Access Trade dengan menggunakan sistem $C P A$.

Para pemilik bisnis yang ingin mempromosikan atau mengiklankan bisnisnya di Access Trade disebut Advertiser, pada setiap transaksi pasti selalu ada akad di dalamnya, tidak terkecuali juga pola hubungan antara Access Trade dan Advertiser ini juga terdapat akad di dalamnya. Pada transaksi antara Access Trade dan Advertiser menggunakan akad ijarah, berikut penjelasan analisis dan alasan mengapa menggunakan akad tersebut:

Para fuqoha Hanafiyah berpendapat bahwa ijarah itu akad atau transaksi terhadap manfaat dengan imbalan (Mas'adi, 2002), pihak Advertiser disini mendapatkan manfaatnya dan Access Trade yang mendapatkan imbalan dari jasa (memberikan 
manfaat). Perlu digaris bawahi dalam menggunakan akad ijarah harus memenuhi rukun dan persyaratannya, adapun rukun dalam ijarah adalah :

\section{Dua Belah Pihak yang Melakukan Akad}

Pada akad ini ada yang disebut sebagai mu'ajir (pihak yang menyewakan) baik itu produk ataupun jasa dan musta'jir (pihak yang menyewa), pada kasus ini yang bertindak sebagai mu'ajir adalah Access Trade dan sebagai musta'jir yaitu Advertiser. Mu'ajir harus mampu menyerahkan manfaat yang disewakannya dan dalam kasus ini adalah manfaatnya berupa mengelola budget iklan dari pihak Advertiser. Sudah banyak perusahaan sejenis di Indonesia khususnya yang membuka jasa seperti ini, seperti kliksaya.com, adsensecamp.com, idblognetwork.com, dan lain-lain. Pastinya tujuan dari mereka adalah agar situs para pengiklan banjir visitor secara instan.

Begitu pula pada musta'jir harus mampu dalam mengelola harta (orang dewasa). Musta'jir (Advertiser) pastinya bukanlah orang yang tidak mengerti tentang keuangan atau bisnis yang dijalankan, terbukti dengan memasang iklan kepada Access Trade yang bertujuan agar situs mereka banjir kunjungan. Sudah banyak situs-situs perusahaan yang memakai strategi iklan seperti ini, tujuannya adalah agar situs mereka banjir visitor secara instan tanpa perlu mengoptimasi, seperti menggunakan SE0, dan lainnya.

Sebagai mu'ajir (Access Trade) dan musta'jir (Advertiser), penulis mengidentifikasi bahwa sudah memenuhi salah satu dari rukun dan persyaratan dalam ijarah sebagai keduanya, yaitu dua pihak yang melakukan akad.

\section{Shigat Ijarah}

Ijab qabul merupakan bentuk dari perwujudan suka sama suka, dengan adanya shigat maka menegaskan bahwa mereka telah saling sepakat dalam menjalankan sebuah transaksi bisnis, tidak ada unsur paksaan dalam menjalankannya, sebagaimana dalam firman Allah SWT :

Artinya : Hai orang-orang yang beriman, janganlah kamu saling memakan harta sesamamu dengan jalan yang batil, kecuali dengan jalan perniagaan yang berlaku dengan suka sama-suka di antara kamu. dan janganlah kamu membunuh dirimu Sesungguhnya Allah adalah Maha Penyayang kepadamu. (Q.S An Nisa [29]: 04).

Ayat diatas menegaskan bahwa setiap bisnis harus dijalankan secara suka sama suka, tidak ada unsur merugikan di salah satu pihak dan itu tertuang dengan adanya shigat akad Ijarah tersebut. Ijarah dalam ijab qabul dapat berupa lafadz ucapan ataupun tulisan. Jika kedua belah pihak paham maksud dari shigat, maka ijarah dianggap telah sah. Sebelum terjadi transaksi, disini Advertiser terlebih dulu mengisi form dan wajib menyetejui setiap ketentuan yang dibuat oleh pihak Access Trade, dari pengisian form tersebut telah dianggap sah dalam menjalankan akad ijarahnya.

Pada transaksi ini peneliti melihat bahwa antara Advertiser dan Access Trade telah sah dalam melakukan shigat ijarah, karena Advertiser paham dan menyetujui semua peraturan yang dibuat oleh Access Trade tanpa ada paksaan. Walaupun yang membuat semua aturan tersebut adalah pihak Access Trade, tanpa adanya diskusi langsung bersama pihak Advertiser. Tetapi yang perlu digaris bawahi disini adalah pihak Advertiser setuju dengan itu semua.

\section{Imbalan (Ujroh)}


Untuk imbalan, Advertiser membayar kepada Access Trade dari setiap iklan yang mereka sepakati, contoh pada kasus ini, Advertiser beriklan dengan kuota 1000 klik yang menuju ke websitenya dan jika telah habis maka Advertiser akan membayar Access Trade harga yang telah mereka sepakati sebelumnya. Dalam dunia online telah menjadi hal lumrah bahwa pembayaran dibayar diawal akad agar terhindar dari ketidak adilan dalam transaksi, mengapa? Karena jika Access Trade melakukan penipuan, dapat dilacak dengan alamat kantor mereka atau rekening, oleh karena itu sebaiknya ketika membeli online pastikan untuk cek keaslian dari jasa atau barang yang dibeli itu malalui website yang mereka cantumkan.

Syarat imbalan yang harus dipenuhi adalah harus diketahui, sifat, kadar, dan jenisnya layaknya sebuah jual beli. Karena ijarah merupakan akad yang berorientasi keuntungan, yaitu tidak sah tanpa menyebutkan nilai kompensasi. Sudah hal lumrah bahwasanya ketika membuka sebuah jasa, maka yang memiliki jasa memasang tarif dalam bentuk uang dan ini telah sesuai dengan syarat dari imbalan yang harus dipenuhi oleh penyewa.

\section{Hak Pakai (Manfaat)}

Dalam pemanfaatan pemakaian jasa, maka ada dua jenis yang di manfaatkan, yaitu pemanfaatan dalam harta benda dan pemanfaatan dalam suatu pekerjaan. Dalam kasus ini Advertiser menyewa sebuah jasa dalam bentuk pekerjaan kepada pihak Access Trade, bukan berbentuk harta benda seperti yang sering terjadi, misalnya penyewaan mobil, kontrakan, tenda, dan lain sebagainya.

Sebagaimana dalam kaidah fikih bahwa dalam pemanfaatan ini terdapat syarat yang harus dipenuhi, yaitu :

- Perbuatan tersebut harus jelas batas waktu pekerjaannya, dalam kasus ini pihak Advertiser dapat memilih target penyelesaian pekerjaan yang dibebankan kepada Access Trade, seperti jika tercapai kuota yang telah dipenuhi, seperti 1000 klik, 1000 lead, atau 1000 sale, maka kontrak selesai atau pilihannya dapat diperbaharui kembali.

- $\quad$ Pekerjaan yang menjadi objek ijarah tidak berupa pekerjaan yang telah menjadi kewajiban pihak mustajir (Access Trade) sebelum terjadi akad ijarah, seperti kewajiban membayar hutang atau mengembalikan pinjaman. Hal seperti ini mungkin tidak terjadi pada kasus diatas, karena penyedia jasa sebelumnya tidak mengenal Advertiser.

Dari ke empat syarat dan rukun dalam ijarah yang telah disebutkan diatas, bahwasanya transaksi antara pihak Advertiser dan Access Trade memenuhi syarat dan rukun yang harus dipenuhi, jadi tidak terdapat hal-hal yang mengakibatkan transaksi diatas terlarang.

\section{Hubungan Hukum Terhadap Sistem CPA Antara Access Trade Kepada Publisher}

Pada akad yang terjadi antara Access Trade dan publisher adalah akad Ju'alah, Alasan menggunakan akad Ju'alah karena terdapat pemberian upah dari Access Trade per actionnya atas kepiawan publisher dalam mendatangkan pengunjung dan membuat pengunjung tersebut melakukan action. Berikut analisis mengapa transaksi antara Access Trade dan publisher menggunakan akad Ju'alah.

\section{Tinjauan Akad Jua'lah Pada Access Trade dan Publisher}


Menggunakan akad Ju'alah karena terdapat pemberian upah dari Access Trade per actionnya kepada publisher atas kepiawannya dalam mendatangkan pengunjung dan membuat pengunjung tersebut melakukan action. Akad jua'lah lebih cocok pada bisnis CPA antara Access Trade dan publisher daripada akad sejenis (ijarah), dengan beberapa alasan yang berdasarkan syarat ketentuan hukum dalam Ju'alah dan dalil dari pendapat para ulama di bawah ini.

Dalam fatwa DSN MUI terdapat syarat ketentuan akad yang harus dipenuhi dalam sebuah transaksi akad Ju'alah, yaitu :

\section{Ketentuan Akad}

Akad Ju'alah boleh dilakukan untuk memenuhi kebutuhan pelayanan, ketentuan akad tersebut adalah sebagai berikut:

a. Pihak Ja'il harus memiliki kecakapan hukum dan kewenangan (muthlaq altasharruf) untuk melakukan akad. Pihak ja'il (Access Trade) disini, sebuah website profesional yang didirikan oleh PT Interspace. Untuk kecakapan hukum dan kewenangan dalam transaksi, Access Trade sudah terpenuhi pastinya.

b. Objek Ju'alah (mahal al-'aqd/maj'ul 'alaih) harus berupa pekerjaan yang tidak dilarang oleh syari'ah. Objek Ju'alah yang dikerjakan publisher adalah mendapatkan action dari sebuah iklan, disini publisher terserah memilih iklan yang dipilihnya, tentunya tidak boleh memasarkan produk yang dilarang oleh syari'ah, seperti iklan bank konvensional, perusahaan pinjaman uang berbunga yang terdapat riba, dan produk yang dilarang dalam syari'ah.

c. Imbalan Ju'alah (reward/'iwadh//ju'l) harus ditentukan besarannya oleh Ja'il dan diketahui oleh para pihak pada saat penawaran. Imbalan Ju'alah yang diterima maj'ul lah (publisher) sangat jelas terlihat di member area berupa harga per action.

d. Hasil pekerjaan (natijah) sebagaimana dimaksud harus jelas dan diketahui oleh para pihak pada saat penawaran. Hasil pekerjaan yang harus dicapai maj'ul lah (publisher) adalah action, jika tidak mendapatkan action, maka tidak akan mendapatkan komisi dan action yang harus didapatkan agar mendapatkan pencairan adalah sebesar Rp 500.000

e. Tidak boleh ada syarat imbalan diberikan di muka (sebelum pelaksanaan objek Ju'alah). Dalam pratek antara Access Trade dan publisher disini, maj'ul lah atau publisher tidak ada sama sekali mendapatkan imbalan jika belum menyelesaikan objek Ju'alah (mendapatkan action).

Dari lima ketentuan akad diatas, praktek Access Trade dan publisher sudah memenuhi ketentuan akad sebagai ja'il dan maj'ul lah.

Alasan lain hubungan praktek ini menggunakan akad Ju'alah dibandingkan dengan akad lain (ijarah), Ju'alah lebih longgar ketentuannya (Nawawi, Islamic Softwear International) Ju'alah lebih lebih longgar hukumnya bila dibandingkan dengan ijarah, karena di dalamnya diperbolehkan tidak ditentukannya orang yang melakukan, dan juga ketidakjelasan mengenai pekerjaan yang dimaksudkan. Sedangkan Ijarah tidak sah dilakukan atas sesuatu yang tidak jelas dan tidak spesifik, sehingga lebih sempit hukumnya.

Diantara ciri akad Ju'alah adalah, upah tidak diberikan sebelum apa yang dipersyaratkan benar-benar tercapai dan selesai. Masih dalam kitab al-Majmu' (Nawawi, 
Islamic Softwear International), Imam Mushonnif mengatakan dalam Ju'alah orang yang melakukan pekerjaan tidak berhak atas upah/hadiah kecuali karena selesainya pekerjaan. Jika seseorang menetapkan hadiah atas pengembalian budak yang hilang, kemudian ada orang yang mengembalikannya ke pintu rumah, tapi budak tersebut lari atau mati sebelum diterima oleh pemiliknya, maka orang yang mengembalikan tadi tidak berhak sesuatu pun dari upah/hadiah. Karena, yang dimaksud adalah pengembalian budak dan upah/hadiah adalah imbalannya, sedangkan dalam hal ini tujuan tersebut tidak terwujud.

Dapat disimpulkan dari pendapat mushonnif, bahwa dari ciri-ciri akad dalam Ju'alah adalah :

1. Upah diberikan ketika akhir akad, tidak diawal maupun ditengah.

2. Proses dalam sebuah usaha yang dijalankan tidak dihargai, dalam arti tidak diberikan upah atas proses yang dilakukan, tetapi yang dinilai adalah hasilnya.

Ketentuan tersebut tidak berlaku pada ijarah, artinya dalam ijarah dimungkinkan pemberian upah ditengah atau sebelum berakhir pekerjaan, artinya yang dihargai bukan hasilnya saja, tetapi proses dalam pelaksanaan tugas tersebut juga. Sehingga jika akad ijarah dihentikan oleh salah satu pihak, maka pekerja berhak mendapatkan upahnya, walaupun hasil yang didapat belum ada, karena proses dalam pengerjaan tersebut juga dinilai.

Kembali pada pembahasan CPA antara Access Trade dan publisher, maka semakin terlihat jelas bahwa pada sistem $C P A$ tidak terjadi akad ijarah, tetapi akad yang lebih cocok adalah jua'lah. Dengan diperkuat alasan bahwa dalam $C P A$, publisher belum berhak mendapatkan upah/komisi sebelum dia mendatangkan visitor kemudian mengkonversinya menjadi sebuah action. Jika publisher sudah berusaha mendatangkan action dari visitornya tetapi belum berhasil, dia juga belum berhak atas upah dan komisinya.

Seandainya dalam CPA memakai akad ijarah, maka proses usaha dari pihak publisher harus dihargai dengan bentuk pemberian upah/komisi, tetapi pada kenyataan yang terjadi tidaklah demikian, publisher menerima upah/komisi hanya ketika sudah mendapatkan action.

\section{Tinjauan Pemberian Komisi yang Diterapkan Access Trade}

Komisi merupakan hal yang ditunggu bagi publisher karena prestasinya yang telah diperoleh yang telah ditetapkan oleh pihak Access Trade. Komisi diberikan jika publisher tersebut telah mencapai batas minimal payout yang telah ditetapkan oleh Access Trade yaitu Rp 500.000 dan ini dapat dicairkan kapan saja jika telah mencapai nominal tersebut.

Pemberian upah atau komisi setelah melaksanakan pekerjaan telah banyak disebutkan dalam sumber hukum Islam. Salah satunya adalah pada hadits riwayat Ibnu Majah (Asqalani, 1992) :

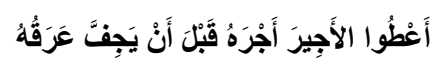

Artinya : Bayarlah upah atau gaji itu sebelum kering keringat pekerjaannya. (HR Ibnu Majah)

Dari hadits diatas dapat dipahami bahwa ketika telah melaksanakan pekerjaan maka seketika itu pula mendapatkan upah atau komisi. Dalam bisnis CPA, komisi publisher dihitung jika terjadi action dan akan tercatat otomatis oleh sistem serta dapat terlihat di 
member area masing-masing akun publisher, tetapi walaupun sudah terkumpul, publisher belum bisa mencairkan komisi tersebut sebelum mencapai Rp 500.000 di dalam saldo mereka.

Menurut hadits di atas dianjurkan pembayaran upah harus langsung dibayarkan setelah pekerjaan selesai, namun Sayid Sabiq menjelaskan bahwa menangguhkan hukumnya juga sah dengan syarat atas kerelaan kedua belah pihak sesuai dengan kesepakatan bersama. Misalnya pembayaran upah karyawan atau pegawai yang dibayar pada akhir bulan meskipun bekerja setiap hari (Sabiq, 1988).

Pada kasus ini, publisher sebelumnya sudah mengetahui bahwa syarat dari minimal payout adalah Rp 500.000, jadi dengan sudah membaca peraturan yang dibuat oleh pihak Access Trade, maka pihak publisher pun sudah menyetujui apa yang telah ditentukan tanpa ada paksaan sama sekali. Selain itu, akad yang digunakan adalah Ju'alah, yang mana harus memenuhi dan mencapai target terlebih dahulu selanjutnya baru bisa mendapatkan komisi.

\section{SIMPULAN}

Setelah penulis membahas praktek dan tinjauan fikih muamalah terhadap praktek bisnis CPA di www.AccessTrade.co.id antara advertiser, Access Trade, dan publisher ini, maka penulis dapat menarik kesimpulan:

Pertama, Dalam praktek sistem CPA di www.accesstrade.co.id, terdapat pihak yang saling berhubungan, yaitu hubungan antara advertiser dan Access Trade, kemudian hubungan Access Trade dan publisher. Masing-masing juga memiliki akad yang berbeda, yaitu advertiser dan Access Trade menggunakan akad ijarah, sedangkan Access Trade dan publihser menggunakan akad Ju'alah.

Kedua, Hubungan hukum antara pihak advertiser kepada Access Trade menggunakan akad ijarah, karena advertiser menggunakan jasa Access Trade untuk mempromosikan usahanya dan hubungan hukum antara pihak Access Trade kepada publisher menggunakan akad Ju'alah, karena publisher diberi komisi oleh Access Trade sebagai kompensasi karena telah mendapatkan action, dengan syarat sudah mencapai minimal pay out.

Harapan untuk penelitian selanjutnya, dapat meninjau lebih dalam dengan mengupas secara tuntas dengan hitung-hitungan cara pembagian fee untuk publisher yang diberikan oleh Access Trade dan fee yang didapat oleh Access Trade

\section{DAFTAR PUSTAKA}

Antonio. M.S (2001). Bank Syariah Dari Teori ke Praktek, Jakarta: Gema Insani Press.

Asqalani I.H (1992). Terj. Bulughul Maram Jilid 1, Terj : Masyhur. K.Jakarta: Rineka Cipta. Basyir. A. A (2000). Asas-Asas Hukum Muamalat (Hukum Perdata Islam), Yoyakarta: UII Press

Bukhari. I (1992). Sahih al-Bukhari. Beirut : Darul Kutub Al-Ilmiyah

Bukhari. I (2005). Shahih al-Bukhari. Bairut : Darul Al-Fikr

Data Transaksi E-Commerce Terkenal di Indonesia. Retrieved Februari 16, 2015, From : www.sharingvision.com

Dewi. G. (2005). Hukum Perikatan Islam Indonesia, Jakarta: Kencana

Djuwaini. D (2008). Pengantar Fiqh Muamalah, Yogyakarta : Pustaka Pelajar 
86 | Firmansyah \&Hafizh: Tinjauan Flqih Muamalah Terhadap Praktek Bisnis Cost Per Action (CPA)......

Fatwa DSN MUI NO: 09/DSN-MUI/IV/2000: Pembiayaan Ijarah. Retrieved Oktober 10, 2015, From : www.dsnmui.or.id

Fatwa DSN MUI NO: 62/DSN-MUI/XII/2007 : Akad Ju'alah. Retrieved Oktober 10, 2015, From : www.dsnmui.or.id

Hasyimiy. M.M.Z (2008). MA, Sistematika Teori Hukum Islam (Qowa'id - Fiqhiyyah), Jombang : Darul Hikmah

Helft, M. (2007). “Google tests an ad idea: Pay only for results," New York Times, Mar 21.

Jaribah. (2006). Fikih Ekonomi Umar Bin Khattab. Terj : Asmuni Solihan Zamakhsari. Jakarta: Khalifa

Jony. W. (2010). Internet Marketing for Beginners. Jakarta : Elex Media Komputindo

Lungan R. (2006). Aplikasi Statistika dan Hitung Peluang. Yogyakarta: Penerbit Graha Ilmu

M. Mahdian, and K. Tomak. (2007). Pay-per-action model for online advertising. Proceedings of the 3rd International Workshop on Internet and Network Economics.

Mas'adi. G.A. (2002). Fiqh Muamalah Kontekstual, Jakarta : PT. Raja Grafindo Persada

Moehar. D (2001) Metode Penelitian Sosial Ekonomi, Jakarta: Bumi Aksara

Moleong. L.J (2004). Metodologi Penelitian Kualitatif, Bandung: PT Remaja Rosdakarya

Muhammad. (1999). al-Lum'ah al-Dimsyiqiyyah juz 3, Beirut : Dar at-Ta'arif li alMatbu'ah.

Nasroni. A.G (2007). Payung Hukum Perbankan Syari'ah. Yogyakarta : UII Press

Nasrun.H. (2007). Fiqh Muamalah, Jakarta : Gaya Media Pratama

Nawawi. I Al-Majmu' fi Syarh al-Muhadzdzab. CD Maktabah al-Fiqh al-Islamy. Islamic Softwear International

Nazerzadeh. H. et.al. (2008). Dynamic Cost-Per-Action Mechanisms and Applications to Online Advertising.

Publisher yang Mendaftar di Access Trade. Retrieved Februari 16, 2015, From : www.facebook.com/groups/accesstrade.blogger.id/

Prasetio. A (2012). Smart Guide Jualan Online. Jakarta: Media Kita

Abdullah, et.al. (2009). Ensiklopedi Fikih Muamalah Dalam Pandangan 4 Madzhab. Jogjakarta : Maktabah Al-Hanif

Profil Lengkap Access Trade. Retrieved September 23, 2015, From : www.interspace.co.id/ en/products.html

Ruslan. (2006). Metode Penelitian Publik Relation dan Komunikasi, Jakarta: Raja Grafindo Persada

Sabiq. S (1988). Fikih Sunnah Jilid 12. Terj : Mahyuddin Syaf. Bandung: Al Ma'arif.

Sabiq. S. (1987). Fikih Sunnah Jilid 13. Terj : Mahyuddin Syaf. Bandung : PT Al Ma'arif

Sabiq. S. (2008). Fikih Sunnah. Terj : Nur Hasanuddin. Jakarta : Pena Pundi Aksara

Statistik Pengguna Internet di Indonesia. Retrieved Februari 10, 2015, From : www.apjii.or.id/read/content/Statistik/305.html

Sugiyono. (2003). Metode Penelitian Bisnis, Bandung : Alfabeta

Suhendi. H (2005). Fikih Muamalah. Jakarta : PT Raja Grafindo Persada

Surakhmad. W (1990). Pengantar Penelitian Ilmiah: dasar, metode dan teknik. Bandung: Tarsito

Syarbini. S. (1997). Mugni al-Muhtaj juz 3. Beirut : Darul Kutub Al lmiyah

Taufik. H (2008). Panduan Membuat Toko Online dengan OS Commerce, Jakarta : Mediakita

Wahyono. T (2006). Etika Komputer Dan Tangung Jawab Profesional Di Bidang Teknologi Informasi. Yogyakarta: Andi

Zuhaili. W (1989) Al-Fiqh al-Islami wa Adillatuhu juz 5, Beirut : Darul Kutub

Zuhaili. W (2010). Fikih Imam Syafi'i Mengupas Masalah Fiqhiyyah Berdasarkan AlQur'an dan Hadits 2, Terj : Muhammad Afifi, Abdul Hafiz. Jakarta : Almahira 